\title{
Isolation and Characterization of the Outer Membrane Proteins of Azospirillum brasilense
}

\author{
By ANAND K. BACHHAWAT AND SUDHAMOY GHOSH* \\ Department of Biochemistry, Bose Institute, Acharya J. C. Bose Centenary Building, P-1/12, \\ CIT Scheme VII M, Calcutta 700054, India
}

(Received 22 July 1986; revised 11 February 1987)

The outer membrane of Azospirillum brasilense was isolated from the total membrane fraction by sucrose density gradient centrifugation and by Sarkosyl extraction; both preparations showed an identical outer membrane protein profile in slab gels after electrophoresis under denaturing conditions. The profile showed a major $42 \mathrm{kDa}$ protein constituting about $60 \%$ of the total outer membrane proteins. This major protein and a minor $40 \mathrm{kDa}$ protein were tightly but noncovalently associated with peptidoglycan. In addition, a $23 \mathrm{kDa}$ heat-modifiable protein, resistant to trypsin digestion, was detected in the outer membrane. Growth of $A$. brasilense under iron deficiency induced four additional high molecular mass proteins $(87,83,78$ and $72 \mathrm{kDa})$ in the outer membrane. A comparison of the outer membrane protein profiles of the three different Azospirillum species suggests that such profiles might be useful in taxonomic classification.

\section{INTRODUCTION}

Azospirillum species are Gram-negative soil bacteria that fix nitrogen under microaerophilic conditions both in isolated cultures and in their unique kind of association with roots of members of the grass family, including many important cereal crops (Von Bulow \& Dobereiner, 1975; Umali-Garcia et al., 1980; Van Berkum \& Bohlool, 1980). Most of the bacteria belonging to the genus Azospirillum have been classified within the two species $A$. brasilense and $A$. lipoferum, depending on their nutritional characteristics and DNA homology (Tarrand et al., 1978). Recently, a new species, A. amazonense (Magalhaes et al., 1983), has been identified within this genus by modifying the selection procedure (Falk et al., 1985), an approach which may reveal further new species of Azospirillum (Franche \& Elmerich, 1981).

In addition to root colonization activity, chemotaxis of Azospirillum towards different nutrients has also been demonstrated (Barak et al., 1983; Heinrich \& Hess, 1985; Reinhold et al., 1985). It is likely that the outer membrane has an important role in chemotaxis and in 'associative symbiosis', possibly via specific recognition properties inherent in some of the outer membrane proteins. Several workers have suggested the existence of species-specific differences in the cell surface of Azospirillum species based on their preferential association with specific plant roots (Baldani \& Dobereiner, 1980; De-Polli et al., 1980), but this has not been definitely established (Elmerich, 1984). Although the cell envelope proteins of many Gram-negative bacteria, particularly members of the Enterobacteriaceae (Lugtenberg \& Van Alphen, 1983) are well characterized, no information is available on the outer membrane proteins of Azospirillum species. Differences in outer membrane protein profiles reflect changes in growth conditions (Sterkenburg et al., 1984; Brown \& Williams, 1985). For example, when iron becomes growthlimiting, induced synthesis of a number of proteins has been observed (Williams et al., 1984; Hoe et al., 1985; Neilands, 1982). Some of these act as receptors for high-affinity ironsiderophore uptake systems (Neilands, 1982). Studies with some rhizobacteria (Schroth \&

Abbreviations: LBS, Luria broth-succinate; SMM, succinate minimal medium- $\mathrm{NH}_{4} \mathrm{Cl}$; LB Sucr, Luria brothsucrose; EDDA, ethylenediamine-di(o-hydroxyphenylacetic acid). 
Hancock, 1982) and the identification of siderophores in soil samples (Powell et al., 1983) provide strong indications that soil microbes face an iron-deficient environment.

We report here the isolation of the outer membrane of $A$. brasilense and the identification of its associated proteins including those induced under iron deficiency. We have also compared outer membrane protein profiles of different members of the genus Azospirillum in an attempt to identify species-specific differences in their cell surfaces.

\section{METHODS}

Bacteria. The major part of this study was done with $A$. brasilense RG, a strain isolated as a spontaneous streptomycin-resistant colony (Maulik \& Ghosh, 1986) from a culture of $A$. brasilense sp. 81 obtained from N. R. Krieg (Virginia Polytechnic Institute, USA). A. brasilense sp. 7, A. lipoferum 59b and A. amazonense $\mathrm{Y} 1$ were also obtained from N. R. Krieg. A. brasilense K67 was obtained from C. Elmerich (Pasteur Institute, Paris).

Media and growth conditions. A. brasilense and A. lipoferum were grown in Luria broth (Miller, 1972) supplemented with $0.1 \%$ sodium succinate and adjusted to $\mathrm{pH} 7.0$, (LBS), or in the succinate minimal medium of Okon et al. (1976) supplemented with $0.1 \% \mathrm{NH}_{4} \mathrm{Cl}(\mathrm{SMM})$. A. amazonense $\mathrm{Y} 1$ was grown in Luria broth supplemented with sucrose $\left(5 \mathrm{~g}^{-1}\right)$ and adjusted to $\mathrm{pH} 6.0$ (LB Sucr). The bacteria were grown at $32^{\circ} \mathrm{C}$ in a shaker-incubator (100 r.p.m.).

Preparation of crude cell envelope. Unless otherwise stated, all operations described below were done at $0-4{ }^{\circ} \mathrm{C}$. Exponential phase cells $\left(\mathrm{OD}_{590}=0.6-1.0\right)$ grown in LBS or LB Sucr medium were harvested $(6000 \mathrm{~g}, 5 \mathrm{~min})$, washed with Tris/ $\mathrm{HCl}$ buffer ( $10 \mathrm{mM}, \mathrm{pH} \mathrm{8.0)}$ (subsequently referred to as 'Tris buffer'), and resuspended in the same buffer containing $15 \%(\mathrm{w} / \mathrm{v})$ sucrose. The cells were disrupted in an ultrasonic disintegrator and the cell lysate was digested with DNAase and RNAase $\left[20 \mu \mathrm{g}\right.$ of each $\left.(\mathrm{ml} \mathrm{lysate})^{-1}\right]$ for $20 \mathrm{~min}$. The lysate, after removing intact cells and cell debris by low-speed centrifugation, was diluted with Tris buffer ( 2 vols) and centrifuged for $60 \mathrm{~min}$ at $100000 \mathrm{~g}$ in a Beckman ultracentrifuge. The pellet, constituting the 'crude envelope fraction', was resuspended in Tris buffer and further purified by washing and centrifuging at $100000 \mathrm{~g}$ using the same buffer.

Isolation of the outer membrane. (a) By density gradient centrifugation. The procedure was a modification of that of Hancock \& Carey (1979). The 'crude envelope fraction' was centrifuged, after layering onto a $45-70 \%$ linear sucrose gradient in Tris buffer for $5.5 \mathrm{~h}$ in a Beckman 50.2 fixed angle rotor at 44000 r.p.m. $(180000 \mathrm{~g})$. The three distinct bands formed were collected as fractions, each diluted 10-fold with Tris buffer, and centrifuged at $100000 \mathrm{~g}$ for $1 \mathrm{~h}$; the sedimented pellets were resuspended in Tris buffer and stored at $-20^{\circ} \mathrm{C}$.

(b) By extraction with Sarkosyl NL97. Outer membrane proteins were isolated from the washed crude envelopes by treatment with $0.5 \%$ Sarkosyl NL97 (Ciba-Geigy) for $30 \mathrm{~min}$ at $28^{\circ} \mathrm{C}$ (Filip et al., 1973) followed by centrifugation at $100000 \mathrm{~g}$ for $60 \mathrm{~min}$. The pellet containing the outer membrane was washed once with Tris buffer, collected by centrifugation at $100000 \mathrm{~g}$, resuspended in Tris buffer and stored at $-20^{\circ} \mathrm{C}$.

Isolation of the peptidoglycan-protein complex. The presence of peptidoglycan-associated proteins was demonstrated by solubilizing the crude envelope in SDS-PAGE sample buffer (Lugtenberg et al., 1975) at $60^{\circ} \mathrm{C}$ for $30 \mathrm{~min}$ and sedimenting the peptidoglycan along with the associated proteins by centrifugation at $180000 \mathrm{~g}$ for $90 \mathrm{~min}$. The sedimented material was resuspended, washed with distilled water and collected by centrifugation at $180000 \mathrm{~g}$ for $90 \mathrm{~min}$.

$S D S-P A G E$. Electrophoresis of membrane proteins was done in SDS-polyacrylamide gels as described by Lugtenberg et al. (1975). Protein bands were stained with Coomassie Blue R-250, and destained with $5 \%(\mathrm{v} / \mathrm{v})$ methanol-7.5\% (v/v) acetic acid solution. Densitometric scans were done with a LKB Laser densitometer (2202 Ultroscan). SDS (Sigma) was recrystallized from $80 \%$ (v/v) hot ethanol before use.

Enzyme assays. NADH oxidase and succinate dehydrogenase associated with the membrane preparations were assayed essentially as described by Osborn et al. (1972). One unit of NADH oxidase is defined as the amount of enzyme that catalyses the oxidation of $1 \mu \mathrm{mol} \mathrm{NADH} \mathrm{min}^{-1}$. One unit of succinate dehydrogenase is defined as the amount that brings about a change of $1.00 \mathrm{OD}$ unit $\min ^{-1}$ at $550 \mathrm{~nm}$ using phenazine methosulphate $(\varepsilon=1.93$ $\left.\times 10^{4}\right)$ in the presence of 3-(4,5-dimethyl-2-thiazolyl)-2,5-diphenyltetrazolium bromide.

Protein was estimated by the dye binding method of Bradford (1976).

\section{RESULTS}

Isolation of outer membrane by sucrose density gradient centrifugation

Sucrose density gradient centrifugation separated the crude envelope into three bands which could be collected as three distinct membrane fractions with densities $\left(\mathrm{g} \mathrm{ml}^{-1}\right)$ of $1.15,1.19$ and 1.24. The bands contained $0.56,0 \cdot 10$ and 0.018 units of NADH oxidase, $2 \cdot 29,0.97$ and 0.075 units of succinate dehydrogenase, respectively. These results indicate that the cytoplasmic 


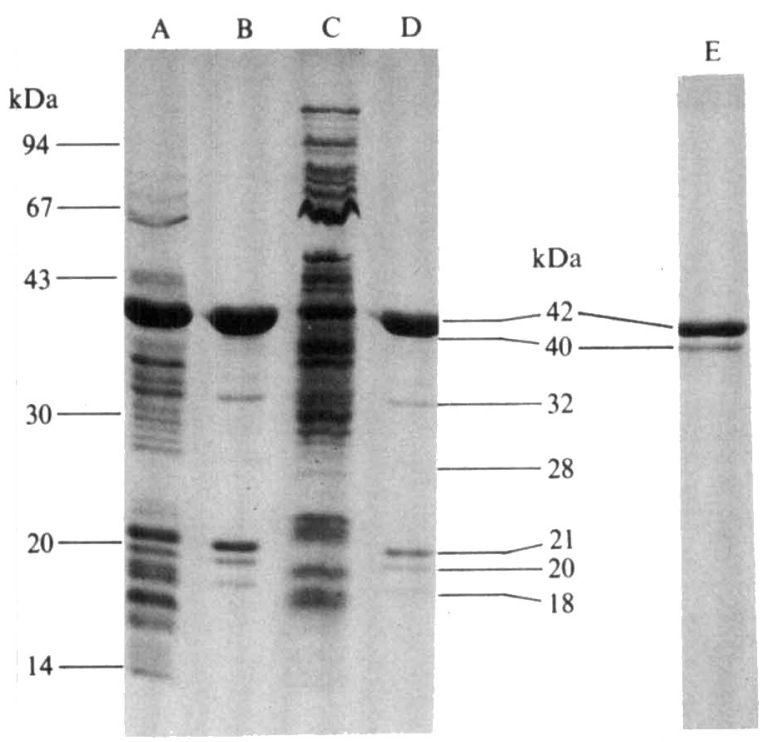

Fig. 1

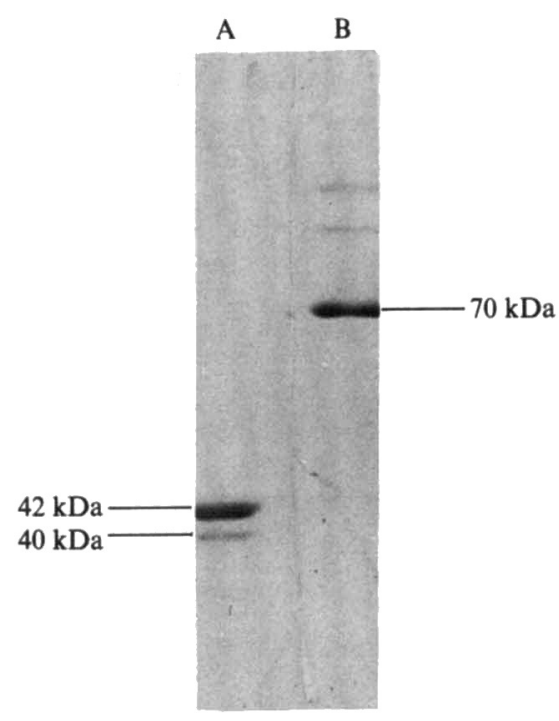

Fig. 2

Fig. 1. SDS-PAGE $(12 \%, w / v$, acrylamide) of the membrane proteins of $A$. brasilense RG. A, Crude envelope; B, outer membrane proteins isolated by sucrose density gradient centrifugation; $C$, inner membrane proteins isolated by sucrose density gradient centrifugation; $D$, outer membrane proteins isolated by Sarkosyl extraction of crude envelope; E, peptidoglycan-associated proteins isolated as described in Methods. The pointers indicate molecular mass values: pointers on the left show the positions of standard molecular mass marker proteins; pointers in the middle indicate molecular masses of outer membrane proteins.

Fig. 2. SDS-PAGE ( $8 \%$, w/v, acrylamide) showing the oligomeric and monomeric forms of the peptidoglycan-associated proteins. Proteins were released from the peptidoglycan by incubating the peptidoglycan-protein complex in $2 \%(w / v)$ SDS-PAGE sample buffer at $100^{\circ} \mathrm{C}$ for $5 \mathrm{~min}(\mathrm{~A})$ or at $60^{\circ} \mathrm{C}$ for $30 \mathrm{~min}$ in sample buffer containing $0.4 \mathrm{M}-\mathrm{NaCl}(\mathrm{B})$.

membrane was concentrated in the top, lighter fraction. The bottom, heavier fraction banded at a density that corresponded to outer membrane associated with peptidoglycan (Burnell $e$ t al., 1980). This was expected as our method of isolation did not involve digestion of the peptidoglycan. The outer membrane fraction in the bottom layer showed very little contamination with cytoplasmic membrane-associated enzymes but the intermediate fraction appeared to contain unseparated cytoplasmic and outer membrane.

\section{Characterization of outer membrane proteins of A. brasilense RG by SDS-PAGE}

SDS-PAGE gels of the total membrane, the cytoplasmic membrane and the outer membrane isolated by density gradient centrifugation and the Sarkosyl-extracted outer membrane of $A$. brasilense RG are shown in Fig. 1. There was very little cross-contamination between the outer membrane and the cytoplasmic membrane proteins prepared by density gradient centrifugation as revealed by SDS-PAGE analysis (Fig. 1 ; lanes B and C, respectively) and by enzyme analysis. The outer membrane prepared by the Sarkosyl extraction procedure gave a protein profile (Fig. 1 ; lane $\mathrm{D}$ ) identical to that of the outer membrane isolated by density gradient centrifugation (Fig. 1; lane B). All subsequent experiments were therefore done with outer membrane proteins isolated by the more convenient Sarkosyl extraction procedure.

A major outer membrane protein of molecular mass $42 \mathrm{kDa}$ constituted over $60 \%$ of the protein in the outer membrane of $A$. brasilense RG as determined by densitometer tracings of the gel. Other minor proteins were also observed in the gel and they were identified by their molecular mass values as shown in Fig. 1. 


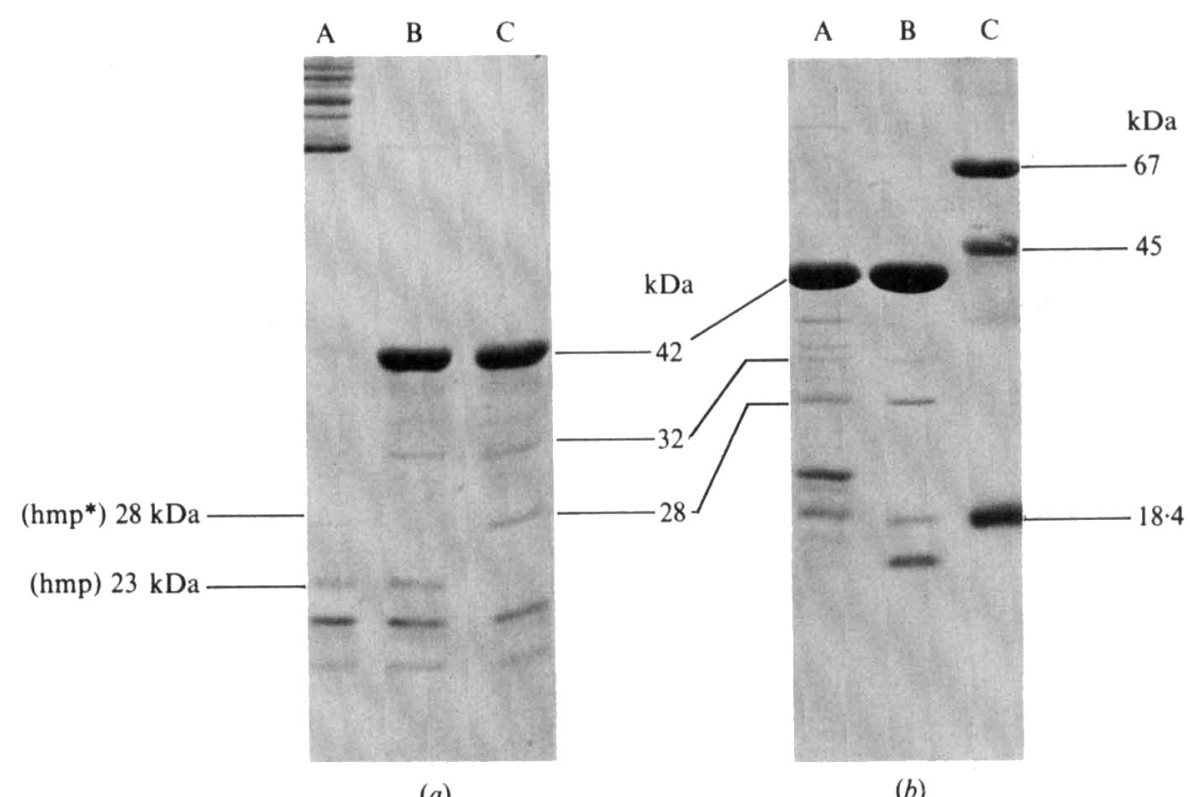

(a)

(b)

Fig. 3. (a) SDS-PAGE (12\%, w/v, acrylamide) of the outer membrane proteins solubilized at different temperatures in $2 \%(w / v)$ SDS-PAGE sample buffer, showing the presence of a heat-modifiable protein: $\mathrm{A}, 30 \mathrm{~min}$ at $60^{\circ} \mathrm{C}: \mathrm{B}, 30 \mathrm{~min}$ at $70^{\circ} \mathrm{C}, \mathrm{C}, 5 \mathrm{~min}$ at $100^{\circ} \mathrm{C}$. Outer membrane proteins were prepared by the Sarkosyl extraction method from cells grown in SMM. hmp, hmp*, see Results. (b) Trypsin sensitivity of the outer membrane proteins of $\boldsymbol{A}$. brasilense RG. Outer membrane proteins prepared as for Fig. 3(a) were incubated in Tris buffer with trypsin [100 $\left.\mu \mathrm{g}\left(\mathrm{mg}^{\mathrm{m}} \text { membrane protein }\right)^{-1}\right]$ for $30 \mathrm{~min}$ at $37^{\circ} \mathrm{C}$. The digested membranes were collected and washed by centrifugation $(100000 \mathrm{~g}$, $60 \mathrm{~min})$ and resuspended in Tris buffer. SDS-PAGE $(12 \%$, w/v acrylamide) of these samples was done before trypsin digestion (lane $\mathrm{A}$ ) or after trypsin digestion (lane $\mathrm{B}$ ); lane $\mathrm{C}$, molecular mass markers.

\section{Peptidoglycan-associated proteins}

The peptidoglycan-associated proteins could be released from the peptidoglycan on incubation of the peptidoglycan-protein complex in $2 \%$ SDS-PAGE sample buffer at temperatures of $70^{\circ} \mathrm{C}$ and above (Fig. 1, lane E; Fig. 2, lane A) or at $60^{\circ} \mathrm{C}$ in the same buffer containing $0.4 \mathrm{M}-\mathrm{NaCl}$ (Fig. 2, lane $\mathrm{B}$ ). This suggests that the major $42 \mathrm{kDa}$ protein and a minor $40 \mathrm{kDa}$ protein are tightly but non-covalently linked to the peptidoglycan. The peptidoglycanassociated proteins released from the peptidoglycan in the presence of $0.4 \mathrm{M}-\mathrm{NaCl}$ at $60^{\circ} \mathrm{C}$ in $2 \%$ SDS-PAGE sample buffer remained in an aggregated or oligomeric form and appeared as high molecular mass bands (Fig. 2, lane B). The predominant oligomer observed on SDS-PAGE corresponded to a molecular mass of $70 \mathrm{kDa}$.

\section{Heat-modifiable proteins}

The solubilization experiments in $2 \%$ SDS-PAGE sample buffer at increasing temperatures revealed the presence of one outer membrane protein that was heat-modifiable (Fig. $3 a$ ). The heat-modifiable protein was solubilized even at $37^{\circ} \mathrm{C}$ and had an apparent molecular mass of $23 \mathrm{kDa}$ (hmp) below $80^{\circ} \mathrm{C}$, but above $90^{\circ} \mathrm{C}$ the same protein had an apparent molecular mass of $28 \mathrm{kDa}\left(\mathrm{hmp}^{*}\right)$. These experiments were done with cells grown in SMM which favoured production of the heat-modifiable protein (2-3-fold compared with cells grown in LBS as determined by Laser densitomer scans). 


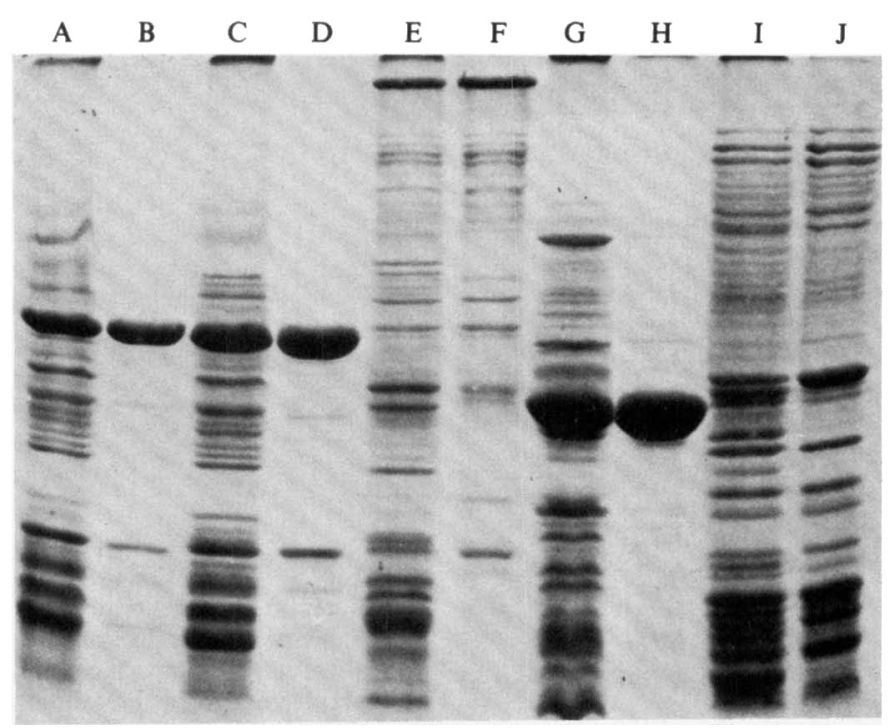

Fig. 4. SDS-PAGE $(12 \%, w / v$, acrylamide) of the crude envelopes (A, C, E, G and I) and outer membrane proteins (B, D, F, H and J) respectively, of different Azospirillum species: A, B, A. brasilense RG; C, D, A. brasilense sp. 7; E, F, A. brasilense K67; G, H, A. lipoferum 59b; I, J, A. amazonense Y1.

\section{Trypsin-sensitivity of the outer membrane proteins}

Sensitivity to proteolytic digestion of the outer membrane proteins, which is an indication of the surface exposure, was tested by treating the isolated outer membrane with trypsin. The trypsin digestion of the outer membrane preparation (Fig. $3 b$ ) showed that the 42,40 and $32 \mathrm{kDa}$ proteins and the heat-modifiable protein $(28 \mathrm{kDa})$ were among the proteins insensitive to trypsin.

\section{Profiles of outer membrane proteins of Azospirillum species}

A comparison of the total membrane and Sarkosyl-extracted outer membrane proteins of $A$. brasilense, $A$. lipoferum and $A$. amazonense was made by SDS-PAGE analysis (Fig. 4). $A$. brasilense sp. 7 had an almost identical profile to that of $A$. brasilense $\mathrm{RG}$. The outer membrane protein profile of strain K67, a strain classified as A. brasilense (Franche \& Elmerich, 1981), was totally different from the others in that relatively larger proportions of the total membrane proteins were not solubilized by Sarkosyl treatment. SDS-PAGE analysis revealed that $A$. lipoferum $59 \mathrm{~b}$ contained a single major outer membrane protein $(35 \mathrm{kDa})$ that constituted approximately $70 \%$ of the total protein in the outer membrane. $A$. amazonense Y1 was characterized by the presence of numerous proteins (i.e. Sarkosyl-insoluble proteins) in the outer membrane, the most prominent of which was the $38 \mathrm{kDa}$ protein.

\section{Effect of iron-limitation on the outer membrane protein profile of $A$. brasilense $R G$}

Growth of cells in iron-limiting conditions resulted in the production of four new proteins in the outer membrane. The molecular masses of these proteins as determined by SDS-PAGE were $87,83,78$ and $72 \mathrm{kDa}$ (Fig. 5). These iron-regulated proteins were solubilized at $60{ }^{\circ} \mathrm{C}$ by $2 \%$ SDS-PAGE sample buffer and therefore they were unlikely to be associated with the peptidoglycan. Furthermore, trypsin digestion of the outer membrane isolated from iron-starved cells resulted in the cleavage of the iron-regulated outer membrane proteins to yield lower molecular mass fragments (data not shown). This suggests that the iron-regulated proteins were exposed and that they probably function as receptors for iron compounds. 


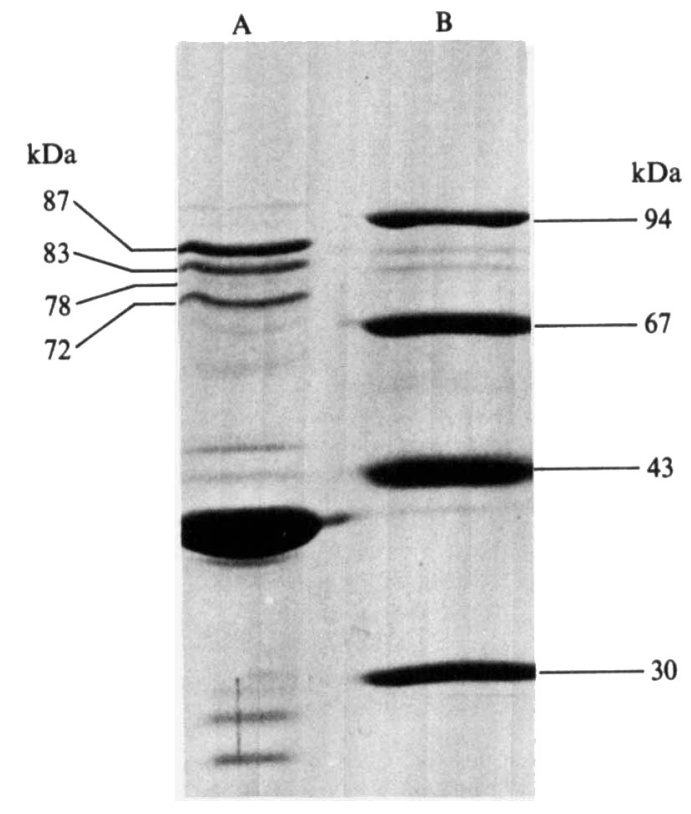

Fig. 5. SDS-PAGE $(8 \%, w / v$, acrylamide $)$ of the outer membrane proteins of $A$. brasilense RG showing the induction of the iron-regulated proteins. A, outer membrane proteins in cells starved of iron by the addition of the iron chelator EDDA $\left(50 \mu \mathrm{g} \mathrm{ml}^{-1}\right)$ to the growth medium (LBS) at an $\mathrm{OD}_{590}$ of $0 \cdot 2$, and harvested after $3 \mathrm{~h}$ at an $\mathrm{OD}_{590}$ of 0.6. B, Molecular mass markers.

\section{DISCUSSION}

As in many Gram-negative bacteria the outer membrane of $A$. brasilense RG contains only a few proteins, and a single $42 \mathrm{kDa}$ protein constitutes over $60 \%$ of the total protein in the outer membrane. This protein, along with another minor $40 \mathrm{kDa}$ protein, is associated with the peptidoglycan, and they probably function as non-specific diffusion channels or porins as has been shown with the peptidoglycan-associated proteins of Escherichia coli, Pseudomonas aeruginosa and Salmonella typhimurium (Lugtenberg \& Van Alphen, 1983). Functional porins are generally formed from the oligomers of these proteins. The peptidoglycan-associated proteins of $A$. brasilense clearly have an oligomeric form although the nature of this oligomer has not been ascertained. The oligomer is stable even in $2 \% \mathrm{SDS}$ at $60^{\circ} \mathrm{C}$ and has a molecular mass of $70 \mathrm{kDa}$ as determined by SDS-PAGE. However, the molecular masses of these complexes are not correctly reflected by SDS-PAGE as most of these proteins have an increased $\beta$-structure and the oligomers bind far less SDS than the monomer (Nakae et al., 1979), which leads to their anomalous electrophoretic mobilities.

An unusual feature of the outer membrane proteins of $A$. brasilense RG is the trypsininsensitivity of the heat-modifiable protein, as hitherto a characteristic feature of the heatmodifiable OmpA protein of $E$. coli and the highly conserved heat-modifiable OmpA-like proteins of other Gram-negative bacteria has been their sensitivity to cleavage by trypsin (Beher et al., 1980).

Comparison of the SDS-PAGE outer membrane protein profiles of different Azospirillum species indicates that the profile is characteristic of each species and could be useful as an aid to taxonomy. For example, strain K67 was previously tentatively classified as $A$. brasilense (Franche \& Elmerich, 1981) but its outer membrane protein profile now suggests that it may belong to a new species completely different from $A$. brasilense, $A$. lipoferum or $A$. amazonense. Although strain-specific chemotaxis has been recently demonstrated in Azospirillum (Reinhold et al., 1985), and strain-specific variations in the outer membrane of Gram-negative bacteria do occur and have been used as a basis of subtyping of species (Barenkamp et al., 1981), the significantly different profile of $\mathrm{K} 67$ from the typical $\boldsymbol{A}$. brasilense profile, and the previous difficulty in classifying this strain (Franche \& Elmerich, 1981), make it difficult to reconcile with the idea that the strain merely belongs to a different subgroup. Among the new isolates of the genus Azospirillum, however, subtyping of species along with species identification may 
become important and outer membrane protein profiles could be an aid to a rapid taxonomic grouping. Furthermore, comparison of the protein profiles of different groups and subgroups could reveal interesting information regarding their association with roots of different plants.

Outer membrane proteins of the phytopathogen Erwinia chrysanthemi induced during ironlimitation have been implicated in the plant pathogenic activity of this bacterium (Expert \& Toussaint, 1985). Moreover, phytopathogenic microbial species are, in general, siderophore producers (Neilands \& Leong, 1986). The four new outer membrane proteins induced under iron-limited growth of $A$. brasilense RG probably act as receptors for iron-containing compounds (accompanying paper: Bachhawat \& Ghosh, 1987) but whether these proteins play any significant role in 'associative symbiosis' remains to be investigated.

We thank Amit Mukherjee, Pushpita Maulik and Anuradha Lohia for helpful suggestions and Asraf Ali Molla for assistance in microbiological work. A.K.B. was supported by a fellowship from the Council of Scientific and Industrial Research, India. This work was partly supported from Grant no. 21(38)/82-STP-II(BT) of the Department of Science and Technology, Govt of India, given to the Genetic Engineering Unit of Bose Institute.

\section{REFERENCES}

BachHaWAT, A. K. \& GHosh, S. (1987). Iron transport in Azospirillum brasilense: role of the siderophore spirilobactin. Journal of General Microbiology 133, 1759-1765.

BALDANI, V. L. D. \& DOBEREINER, J. (1980). Host plant specificity in the infection of cereals with Azospirillum spp. Soil Biology and Biochemistry 12, 434-444.

Barax, R., NuR, I. \& Okon, Y. (1983). Detection of chemotaxis in Azospirillum brasilense. Journal of Applied Bacteriology 53, 399-403.

Barenkamp, S. J., Munson, R. S. \& Granoff, D. M. (1981). Subtyping of Haemophilus influenzae type b by outer membrane protein profiles. Journal of Infectious Diseases 143, 668-676.

Beher, M. G., Schnaitman, C. A. \& Pugsley, A. P. (1980). Major heat modifiable protein in Gramnegative bacteria: comparison with the OmpA protein of E. coli. Journal of Bacteriology 143, 906913.

BRADFORD, M. M. (1976). A rapid and sensitive method for the quantitation of microgram quantities of protein utilizing the principle of protein-dye binding. Analytical Biochemistry 72, 248-254.

Brown, M. R. W. \& Williams, P. (1985). The influence of environment on envelope properties affecting survival of bacteria in infection. Annual Review of Microbiology 39, 527-556.

Burnell, E., Van Alphen, L., VerkleiJ, A., DE KruijifF, B. \& LUGTenberG, B. (1980). ${ }^{31}$ P NMR and freeze-fracture electron microscopy studies on Escherichia coli. Biochimica et biophysica acta 597, 518-532.

De-Polli, H., Bohlool, B. B. \& Dobereiner, J. (1980). Serological differentiation of Azospirillum species belonging to different host plant specificity groups. Archives of Microbiology 126, 217-222.

ELMERICH, C. (1984). Molecular biology and ecology of diazotrophs associated with non-leguminous plants. Biotechnology 2, 967-978.

EXPERT, D. \& TOUSSAINT, A. (1985). Bacteriocin resistant mutants of Erwinia chrysanthemi: possible involvement of iron acquisition in pathogenicity. Journal of Bacteriology 163, 221-227.

FAlk, E. C., Dobereiner, J., JohnSon, J. L. \& KRIEG, N. R. (1985). Deoxyribonucleic acid homology of
Azospirillum amazonense Magalhaes et al. 1984 and emendation of the description of the genus Azospirillum. International Journal of Systematic Bacteriology 35, 117-118.

Filip, C., Fletcher, G., Wulff, J. L. \& Earhart, C. F. (1973). Solubilization of the cytoplasmic membrane of $E$. coli by the ionic detergent sodium lauryl sarcosinate. Journal of Bacteriology 115, 717-722.

Franche, C. \& Elmerich, C. (1981). Physiological properties and plasmid content of several strains of Azospirillum brasilense and A. lipoferum. Annales de Microbiologie 132A, 3-18.

HaNCOCK, R. E. W. \& Carey, A. M. (1979). Outer membrane of Pseudomonas aeruginosa: heat and 2mercaptoethanol-modifiable proteins. Journal of Bacteriology 140, 902-910.

HeINRICH, D. \& Hess, D. (1985). Chemotactic attraction of Azospirillum lipoferum by wheat roots and characterisation of some attractants. Canadian Journal of Microbiology 31, 26-31.

HoE, M., Wilkinson, B. J. \& Hindahl, M. S. (1985). Outer membrane proteins induced upon iron deprivation of Paracoccus denitrificans. Biochimica et biophysica acta 813, 338-342.

LUGTENBERG, B. \& VAN ALPHEN, L. (1983). Molecular architecture and functioning of the outer membrane of Escherichia coli and other Gram-negative bacteria. Biochimica et biophysica acta 737, 51-115.

Lugtenberg, B., Meijers, J., Peters, R., Van Der HOCK, P. \& VAN ALPHEN, L. (1975). Electrophoretic resolution of the major outer membrane protein of $E$. coli $\mathrm{K} 12$ into 4 bands. FEBS Letters 58, 254-258.

Magalhaes, F. M., Baldani, J. I., Souto, S. M., KUYKendalL, J. R. \& DOBEREINER, J. (1983). A new acid tolerant Azospirillum species. Annals Academy Brasil Genc. 55, 417-430.

Maulik, P. \& Ghosh, S. (1986). NADPH/NADHdependent cold labile glutamate dehydrogenase in Azospirillum brasilense. Purification and properties. European Journal of Biochemistry 155, 595-602.

MilleR, J. H. (1972). Experiments in Molecular Genetics, p. 433. Cold Spring Harbor, NY: Cold Spring Harbor Laboratory.

NakaE, T., IshII, J. \& TokunaGa, M. (1979). Subunit structure of functional porin oligomers that form 
permeability channels in the outer membrane of Escherichia coli. Journal of Biological Chemistry 254, 1457-1461.

NeIlands, J. B. (1982). Microbial envelope proteins related to iron. Annual Review of Microbiology 36, 285-310.

NEILANDS, J. B. \& LEONG, S. A. (1986). Siderophores in relation to plant growth and disease. Annual Review of Plant Physiology 37, 187-208.

Okon, Y., Albrecht, S. L. \& BurRis, R. H. (1976). Factors affecting growth and nitrogen-fixation of Spirillum lipoferum. Journal of Bacteriology 127, $1248-1254$.

Osborn, M. J., Gander, J. E., Parisi, E. \& Carson, J. (1972). Mechanism and assembly of the outer membrane of Salmonella typhimurium. Isolation and characterization of cytoplasmic and outer membrane. Journal of Biological Chemistry 247, 39623972.

Powell, P. E., Szaniszlo, P. J. \& Reid, C. P. P. (1983). Confirmation of occurrence of hydroxamate siderophores in soil by a novel Escherichia coli bioassay. Applied and Environmental Microbiology 46, 1080-1083.

Reinhold, B., Hurek, T. \& Fendri, K. I. (1985). Strain specific chemotaxis of Azospirillum species. Journal of Bacteriology 162, 190-195.

SCHROTH, M. N. \& HANCOCK, J. G. (1982). Disease suppressive soil and root colonizing bacteria. Science 216, 1376-1381.
Sterkenburg, A., Viegels, E. \& Wouters, J. T. M. (1984). Influence of nutrient limitation and growth rate on the outer membrane proteins, of Klebsiella aerogenes NCTC 418. Journal of General Microbiology 130, 2347-2355.

TARRAND, J. T., KRIEG, N. R. \& Dobereiner, J. (1978). A taxonomic study of the Spirillum lipoferum group, with description of a new genus, Azospirillum gen. nov. and two new species Azospirillum lipoferum (Beijerinck) comb. nov. and Azospirillum brasilense sp. nov. Canadian Journal of Microbiology 24, 967980.

Umali-Garcia, M., Hubbell, D. H., Gaskins, M. H. \& DAZzo, F. B. (1980). Association of Azospirillum with grass roots. Applied and Environmental Microbiology 39, 219-226.

VAN BERKUM, P. \& BOHLOOL, B. B. (1980). Evaluation of nitrogen fixation by bacteria in association with roots of tropical grasses. Microbiological Reviews 44, 491-517.

Von Bulow, J. F. W. \& Dobereiner, J. (1975). Potential for nitrogen fixation in maize genotypes in Brazil. Proceedings of the National Academy of Sciences of the United States of America 72, 23892393.

Williams, P., Brown, M. R. W. \& Lambert, P. A. (1984). Effect of iron deprivation on the production of siderophores and outer membrane proteins in Klebsiella aerogenes. Journal of General Microbiology 130, 2357-2365. 